\title{
MANFRÉD WEISS - THE ACHIEVEMENTS OF A HUNGARIAN ENTREPRENEUR
}

\author{
József GÁTI, ${ }^{1}$ László NAGY, ${ }^{2}$ János KUTI ${ }^{3}$ \\ Óbuda University, Budapest, Hungary \\ 1 gati@uni-obuda.hu \\ ${ }^{2}$ nagy.laszlo@hok.uni-obuda.hu \\ ${ }^{3}$ kuti.janos@rh.uni-obuda.hu
}

\begin{abstract}
There are several technical inventors in Hungary who unfortunately have been forgotten or are not commemorated sufficiently. One of such Hungarian is Manfréd Weiss. In our research we examine his life and work, a life devoted to our technological development. Moreover, beyond his life, we also explore the famous inventor-engineer's technical achievements and their impacts today. We also study the characteristics of the era in which he lived, in order to better understand the work and context of the inventor better.

I would like to emphasise that during our exploration, we realised the importance of this choice of topic: It is the duty of the later generations to explore and learn the work of their predecessors, and to spread and publish the conclusions as widely as possible.
\end{abstract}

Keywords: history of technology, Manfréd Weiss, biography, ammunition, Csepel

\section{The Weiss Family}

At the end of the $18^{\text {th }}$ century a lot of wealthy Jewish families migrated from Bohemia to Hungary because of an anti-Semitic wave. This was the time when Baruch Weiss, Manfréd Weiss' grandfather, moved to Pest where he had a pipe maker workshop. Manfréd's father, Adolf Weiss was a crop tradesman, and his mother, Éva Kanitz, a noble girl from Buda. Of their six children, Manfréd was the youngest.

Manfréd Weiss was born on $11^{\text {th }}$ April 1857, in Pest. He studied at the Pest Academy of Commerce, later gaining business experience as colonial merchant in Hamburg.

\section{The Origins of the Foundation of the Factory}

The industrial development in Hungary can be dated decades before 1848, when manufacturing started to spread. At that time the dominant industry was the mill industry. And trade connect- ed to the mill industry was the most significant. The agricultural and mill industrial crops were transported to the Austrian market. After the suppression of the revolution it was common in the monarchy that the capital coming from the west territories fuelled industrialization. At the turn of the century only $12 \%$ of the factory owners and the directors, $20 \%$ of the foremen came from other countries of the monarchy, meanwhile this could be said about $75 \%$ of the workers . In this period two forms of factory foundation emerged: -the first form: the heavy machinery industry, with the support of foreign stakeholders;

-the second form: the industrial investments of merchants who made their fortune by export-like agricultural trade.

As a result of the development of the railway between 1860 and 1880, heavy industry started to improve. In the 1880 s the industrial revolution characterized Hungarian industry. Then the manufacturing industry started to evolve by the 1890 s. By the end of the 1860 s, the Weiss family had become industrial capitalists. 


\section{The Beginning of the Company}

In 1877, he joined his brother's, Bertold Weiss' crop company. When the Austro-Hungarian Monarchy occupied Bosnia and Herzegovina from the Ottoman Empire in 1878, the crop supply of the soldiers was shipped by the Weiss brothers among others. On $28^{\text {th }}$ October 1882, the Weiss brothers were granted permission to open their canning factory which was the First Hungarian Canning Factory registered by the court as a company. This was the first canning factory in Hungary at that time. They moved from Lövölde Square to Máriássy Street. Later they started to make cartridge cases, military bottles, ammunitions and other military equipment as well. The can they produced was known by the name Globus. They had to use tin boxes as packages and since the demand for their can had increased they began to produce the tin, too. This activity was already heading towards the iron industry.

Manfréd Weiss' business strategy was to adjust the production to the potential demand against the actual demand, although sometimes this strategy could have caused loss, but they had to risk that in order to be successful later. The brothers had realised soon that making military equipment for the government was a profitable business, thus they started to produce cartridges. However, there was a huge explosion in the meat factory during the production of cartridges, in 1890. Thereafter the authorities did not allow manufacturing ammunition or other explosives on the territory of the canning factory. So they began to look for a new factory site, and they chose the island of Csepel. The Weiss brothers rented a sandy soil area, which was called János's meadow.

They chose the site because it was close to $\mathrm{Bu}$ dapest, the labour and the rent was cheap. They moved the whole factory to Csepel and started to focus on manufacturing products for the armaments industry. The Weiss brothers had already significant capital and a lot of good business relationships, therefore the government also favoured them with various allowances. The land they rented was around five acres. At first they employed around 30-40 men and 100-110 women from the surrounding villages.

The entrepreneurs got permission to establish the industrial plant on $12^{\text {th }}$ January 1893. They bought the land they rented in 1896. By this time there were 20 buildings on the territory and 400 employees were working in the production.

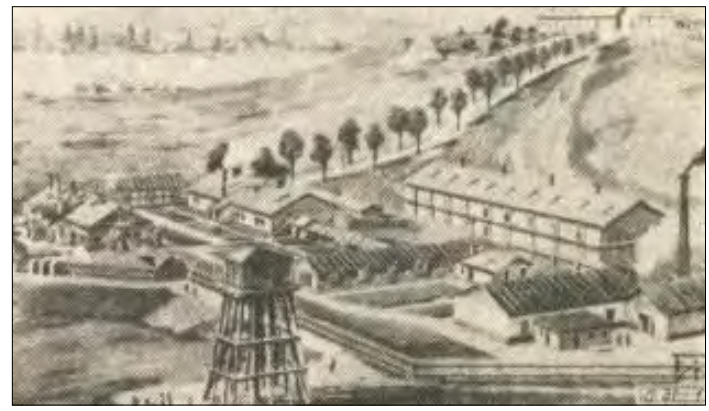

Figure 1. The first factory site at Csepel, on János's meadow [3]

\section{The Hardships of Self-dependence}

In 1896 the brothers were separated since Bertold was elected as a representative of parliament. He had to leave the company because of the law of contradiction: no one could be a representative if he had a company with connections to the Hungarian government.

In the next 20 years, Csepel became one of the biggest centres of heavy industry in Europe. The number of workers was around 150 men in 1893. By 1917 there were already 27000 workers in the factory.

Between 1896 and 1914, the factory became the biggest military factory of the country. It was the biggest private transporter of the Austro-Hungarian Monarchy due to its significant orders, the good family relationships and the production of infantry ammunition. As a result of the development in 1896, the factory already had its own copper metallurgical factory to serve its need of copper. In 1898-1899 the private forge, the water tower, the material tester and other buildings were completed. In 1901 portable kitchens, cooking boxes, camp ovens and other similar military equipment were produced. In 1904 the Csepel factory became the parent company. The trading office was also moved to Csepel. By the autumn of 1907, the metal bar and tube plant was finished as well. In 1911-12 the company began to form its own steel-basis. The steel mill was built with two open-hearth furnaces, which provided the raw material daily.

Manfréd Weiss invested 5 million crowns into the construction of the steel mill, but he requested $42 \%$ of the quota of the $10.4 \mathrm{~cm}$ surface artillery ammunition from the state. In 1911 he made a secret contract with the iron mill of Witkovitz. 


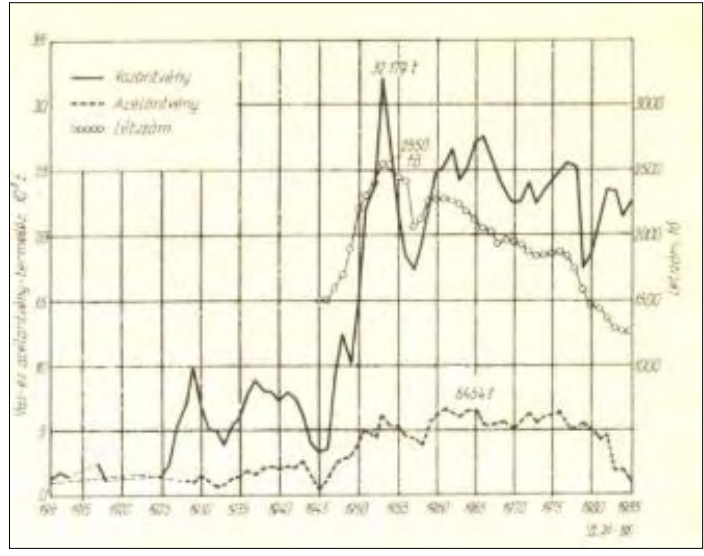

Figure 2. The production of iron and steel moulding and the changes in the number of workers in the Csepel factory [3]

\begin{tabular}{|l|c|c|c|c|}
\hline \multicolumn{1}{|c|}{ Year } & $\begin{array}{c}\text { Number } \\
\text { of work- } \\
\text { ers }\end{array}$ & $\begin{array}{c}\text { Territory } \\
\text { (Acres) }\end{array}$ & $\begin{array}{c}\text { Ground- } \\
\text { space of } \\
\text { the build- } \\
\text { ing (m) }\end{array}$ & $\begin{array}{c}\text { Power } \\
\text { of the } \\
\text { machines } \\
\text { (hp) }\end{array}$ \\
\hline $1892-$ & 25 & 5 & 400 & 4 \\
\hline $1892-1896$ & 920 & 5 & 7500 & 160 \\
\hline $1896-1902$ & 3500 & 60 & 13000 & 546 \\
\hline $1902-1910$ & 5000 & 60 & 40000 & 7000 \\
\hline $1910-1914$ & 10000 & 125 & 100000 & 14000 \\
\hline
\end{tabular}

Figure 3. The development of the Csepel factory in numbers until the World War I. [5]

The main points of the contract stated that:

- the iron mill of Witkowitz is obligated to pass over its experiences from the ammunition production to Manfréd Weiss. It is also to send engineers and workers to Csepel;

- Manfréd Weiss is obliged to pay Witkovitz 3.5\% of every ammunition, which was shipped to the military navy. Witkovitz supports Manfréd Weiss in obtaining the delivery right of 30.5 cannon projectiles from the military navy;

- Manfréd Weiss must buy solely from Witkowitz every item of equipment that can be purchased only abroad;

- Manfréd Weiss is forbidden to pass on any experiences that he gains from Witkovitz not even to those factories where he is part-owner.

When the factory was not yet productive during its initial phase, Manfréd Weiss invested the wealth of the company into real estate. He purchased the area which is now the Jókai Street, Nagymező Street and the southern part of ÚjLipót district; which reached from the Margit
Bridge to the Víg Theatre and Andrássy Street as well. In 1915 he bought the Károlyi Castle of Derekegyháza, too.

The factory was the toughest factory of the era. Manfréd was a workaholic, who wanted to make the most of everything, strictly for the sake of profit. After the World War I started, he knew it could mean a good possibility for his company. He transformed his individual proprietorship into a family corporation. In this period he inducted three shift work schedules in order to increase production output. He extended production with another open-hearth furnace, and he also purchased the first electrofurnace, too. The year 1917 was the best business year for the factory, the General Insurance Company esteemed the value of the Csepel factory to circa 100 million crowns.

\section{Developments in Csepel}

Manfréd Weiss had not just improved his own company, he had also improved Csepel district and its surroundings, and he was charitable as well. When he founded the factory, Csepel was an insignificant small town with just 2200 inhabitants. He built a worker's hostel in accordance with the most modern trends. He also established charity in the factory; the children's home. At the children's home the kids were guarded from their first day until their sixth birthday, which supported the everyday lives of the mothers working in the plant. There was also the people's kitchen in Csepel, in the Ferenc Street, where around 1000 meals were portioned every day. It was the second largest people's kitchen then, where circa 1600000 people were helped during the World War I. A factory hospital was also established in 1916 so that accidents that occurred during production could be tended to fast. However the hospital could be used not only by the workers but by the local people of Csepel as well. There was emergency attendance at the hospital, too. He established the most modern maternity hospital of the age in Budapest, in the memory of his wife in 1910. It was the first hospital to host organized pregnancy counselling and it also had its own educational centre for nurses, too. It was a free hospital, where more than 5000 children were born between 1910 and 1918. In addition, Manfréd also founded a school and a kindergarten for Csepel. As a result of these developments, by 1910 there were already almost 10000 inhabitants in Csepel.

Since his factory started to grow so fast, Manfréd Weiss was elected as the member of board 
of the Hungarian Commerce Bank of Pest and the Confederation of Hungarian Employers and Industrialists. After that he bought the canning factory of Kecskemét and later some textile factories as well.

\section{Honours}

Manfréd Weiss was bestowed by Franz Joseph I Emperor of Austria and King of Hungary with a peerage and noble forename of Csepel on $16^{\text {th }}$ August 1896.

During the world fair of Paris in 1901, he was awarded by the Commander's Cross of the Order of the Iron Crown and the Order of Franz Joseph as acknowledgement of his activities in supplying military equipment. He became member of the upper class in 1915.

On $16^{\text {th }}$ November 1918, Charles I Emperor of Austria and Charles IV as King of Hungary bestowed the title of baron to Manfréd Weiss as one of the greatest ammunition transporters of the Austro-Hungarian Monarchy.

\section{The Family of Manfréd Weiss}

His wife came from Vienna. He married the daughter of an Austrian railway entrepreneur, Alice Wahl, who was a descendant of a family of knights. They had six children in a short time; four daughters and two sons: Elza Weiss, Edith Weiss, Marianne Weiss, Daisy Weiss, Alfons Weiss and Jenő Weiss.

They were strict parents, the time for studying and also the breaks were defined specifically for the children. Manfréd Weiss held musical nights with his family once in every week, when he played the violin and his wife played the piano. According to his grandchildren, their grandfather was a bad sleeper and had often headaches. They lived their everyday lives in their home in Andrássy Street. Manfréd Weiss' wife died of anaemia at the age of 39, in the January of 1904. His sons Jenő Weiss and Alfons Weiss studied engineering so as to assist their father.

\section{The Privatization and its Consequences}

In 1919, during the times of the Soviet Republic, the factory was privatized. The factory was Manfréd's life, thus he tried to commit suicide, but his workers saved his life. When the Romanians marched in Budapest, the factory was dismantled. From 28000 workers only 6000 men remained. After the Peace Treaty of Trianon, the

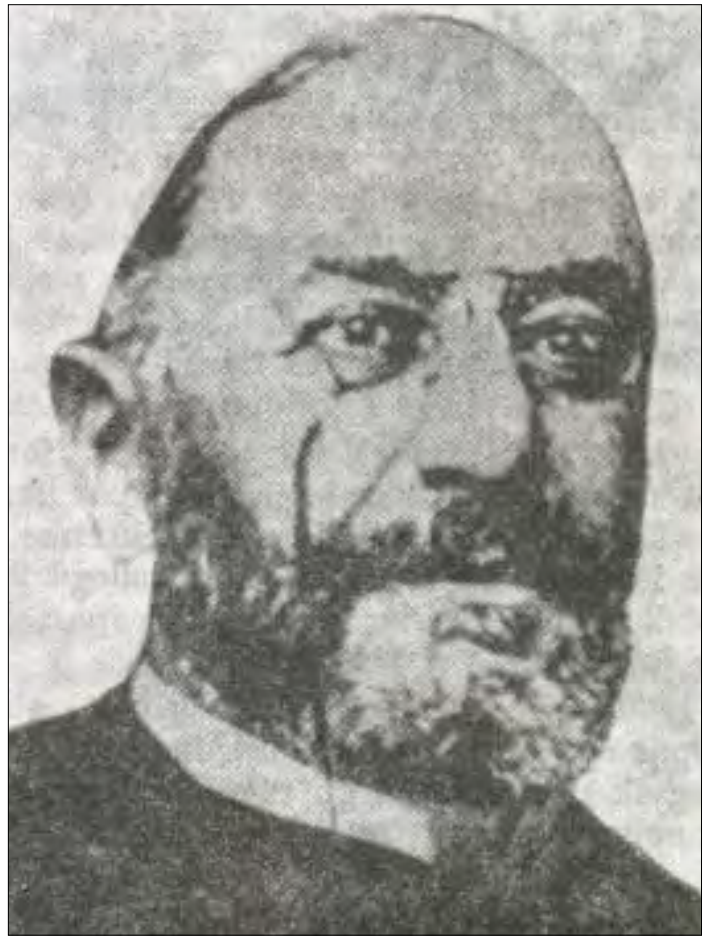

Figure 4. Manfréd Weiss

production shifted from armaments industry to the peace-time products.

After he tried to commit suicide, he was not the same anymore. He died in stroke on 25th of December 1922. The first period of the Csepel factory was ended by the death of Manfréd Weiss.

\section{Summary}

Manfréd Weiss was one of the most brilliant Hungarian industrialists, his technical and economic attitude made him exceptional and one of the greatest factory owners of the era. His life and his work is known by many, however his social work and his treatment of his workers must be emphasized. Because of his personality, strength and his mentality, he is still an outstanding role model for the technical youth.

\section{References}

[1]Lengyel József: 75 éves a Csepeli acélgyártás. Csepeli Müszaki-Közgazdasági szemle 1987/1.

[2] Csepeli müvek II. Ad_275-278-2009, Ad_280-2009.

[3] Rácz József: 75 éves a vas és acélöntvény-gyártás Csepelen, Bányászati és kohászati lapok 38/6.

[4] Kálmán Lajos: 50 éve gyártják vas- és acélöntvényeket Csepelen, Öntöde 14/2.

[5] Czakó Sarolta: A Csepel vas- és fémmüvek rövid áttekintése. Budapest, 1972. 